\title{
Posterior interosseous flap versus reverse adipofascial radial forearm flap for soft tissue reconstruction of dorsal hand defects
}

\author{
Osman Akdağ, M.D., ${ }^{1}$ Gökçe Yıldıran, M.D., ${ }^{1}$ Mustafa Sütçü, M.D., ${ }^{2}$ Mehtap Karameşe, M.D. ${ }^{1}$ \\ ${ }^{1}$ Department of Plastic, Reconstructive and Aesthetic Surgery, Selçuk University Faculty of Medicine, Konya-Turkey \\ ${ }^{2}$ Department of Plastic, Reconstructive and Aesthetic Surgery, Medipol University Faculty of Medicine, İstanbul-Turkey
}

\begin{abstract}
BACKGROUND: Our objective was to compare the outcomes of dorsal hand defect reconstruction using a posterior interosseous artery flap (PIAF) and a reverse adipofascial radial forearm flap (RARFF).

METHODS: From 2008 to 2013, 23 patients who underwent hand soft tissue defect reconstruction with PIAF (II patients) and RARFF ( 12 patients) were included in this retrospective study. Reconstruction methods were compared in terms of functionality with disability of the arm, shoulder, and hand (DASH) score and range of motion (ROM) and aesthetically with scar assessment. Operation times, length of hospital stay, and donor site problems were compared.
\end{abstract}

RESULTS: We found no statistically significant differences between PIAF and RARFF in terms of ROM, DASH score, and length of hospital stay. Statistically significant differences were found in operation time, scar assessment, and donor site problems between PIAF and RARFF patients.

CONCLUSION: RARFF showed better results than PIAF in dorsal hand defects, but in RARFF, the major arteries of the hand are sacrificed.

Keywords: Hand soft tissue defect; posterior interosseous artery flap; reverse adipofascial radial forearm flap; reverse radial forearm flap.

\section{INTRODUCTION}

Hand injuries can occur to anyone, resulting in defect of the soft tissue as well as exposition of the tendons, cartilage, bone, nerves, and joints. Appropriate skin coverage protects the hand's vital structures through which hand functioning is maintained. ${ }^{[1]}$ Optimal soft tissue reconstruction should be easy to perform and should provide the patient with good hand functioning. Although several types of flaps are available for reconstructing dorsal hand defects, posterior interosseous artery flap (PIAF) and reverse adipofascial radial forearm flap (RARFF) techniques are frequently used because of including reliable and pliable tissue. ${ }^{[2]}$ These one-step reconstruction procedures require only one operative field, and the surgeon is able to work with a thin flap that can be conveniently dissected; both techniques result in a high survival rate..$^{[3,4]}$
RARFF is a modification of the classic reverse radial forearm flap that only uses the adipofascial component of the flap; in this procedure, the skin graft is applied over the flap, and then the donor site is successfully treated, resulting in effective reconstruction of the hand soft tissue defect with strong blood supply. We have been performing RARFF instead of traditional reverse radial forearm flap for hand soft tissue defect in our clinic since 2008 , and RARFF provides thin, pliable tissue and causes fewer donors site morbidities than the classic reverse radial forearm flap or PIAF. PIAF has been widely used in the reconstruction of hand soft tissue defects because it is thin and pliable and the flap conforms to the texture of the hand. ${ }^{[5]}$

The choice of flap for hand soft tissue defect reconstruction remains contentious and is often based on the surgeon's pref-

Cite this article as: Akdağ O, Yıldıran G, Sütçü M, Karameşe M. Posterior interosseous flap versus reverse adipofascial radial forearm flap for soft tissue reconstruction of dorsal hand defects. Ulus Travma Acil Cerrahi Derg 2018;24:43-8

Address for correspondence: Osman Akdağ, M.D.

Selçuk Üniversitesi Tıp Fakültesi, Plastik, Rekonstrüktif ve Estetik Cerrahi Anabilim Dalı, Konya, Turkey.

Tel: +90 332 - 6060505 E-mail: oakdag@gmail.com

Ulus Travma Acil Cerrahi Derg 2018;24(I):43-48 DOI: 10.5505/tjtes.2017.4I196 Submitted: 12.03.2017 Accepted: 17.04.2017 Online: 00.00.0000

Copyright 2018 Turkish Association of Trauma and Emergency Surgery 
erences, the vascularity of the hand, the recipient site, and the patient's characteristics. ${ }^{[2]}$ Comparative clinical studies may show long term result about proper flap chose and may be used to guide surgeons in making their choice about which type of flap to use.

In this retrospective study, we analyzed and compared the technical details, outcomes, advantages, and disadvantages of using PIAF and RARFF in 23 patients who underwent dorsal hand defect reconstruction.

\section{MATERIALS AND METHODS}

\section{Patients}

A total of 23 patients (males/females: 15/8) with dorsal hand defects who underwent reconstruction with PIAF or RARFF between January 2008 and December 2013 were retrospectively analyzed. Written informed consent was obtained from each patient prior to surgery. The protocols used in this study were approved by the Selcuk University, Medical Faculty Research Ethics Committee.

The cases of all patients were treated as emergencies. The demographic features of the patients are shown in Table I. All patients had skin defects with exposure of vital hand structures, such as tendons, bones, and joints. To ensure the accuracy and objectivity of the study, only patients with a soft tissue defect on the dorsal side of the hand were chosen. Patients with bone fracture or nerve, tendon, or joint injury were excluded because the presence of these conditions might affect the functional results. In this study, patients who were treated with PIAF comprised the PIAF group and those who were treated with RARFF comprised the RARFF group.

\section{Surgical Techniques}

\section{PIAF}

PIAF was designed according to the size of the defect between the radial and ulnar bones on the dorsal side of the mid-forearm. A line was drawn from the lateral epicondyle to the distal radioulnar joint. Flap dissection was continued radial to the ulnar joint and distal to the proximal direction. The posterior interosseous artery arises from the common interosseous artery or the ulnar artery and travels along the intramuscular septum between the extensor digiti minimi and the extensor carpi ulnaris muscles. ${ }^{[6]}$ To ensure adequate hand coverage, a reverse pattern flap is chosen, and the anastomosis between the anterior interosseous and the posterior interosseous arteries (PIOA) must be preserved. PIOA runs deep alongside the posterior interosseous nerve. The nerve should be preserved during the dissection. The proximal PIOA is clamped before it is ligated to check the vascular supply to the flap. After ligation of PIOA, the flap is passed through a wide subcutaneous tunnel to cover the hand defects (Fig. I).

\section{RARFF}

The flap was designed between the radial and ulnar bones on the volar side of the mid-forearm. After examining the skin, a "lazy-S"-shaped incision was made and the flap was separated from the underlying adipofascial tissue. The size of RARFF was based on the size of the hand defect. The adipofascial flap borders, which included the forearm fascia, were cautiously cut, and the connections between the radial arteries were protected. The radial artery and the concomitant veins were dissected and ligated in the proximal forearm. The flap dissection progressed from the proximal area to the distal area. The pivot point was located $\mathrm{I}-2 \mathrm{~cm}$ above the radial styloid. ${ }^{[7]}$ RARFF was transposed to the defect through a subcutaneous tunnel and then sutured. A skin graft was applied over the flap. The forearm skin that was left at the donor site was then directly sutured (Fig. 2).

\section{Evaluation Criteria}

The mean follow up period for all patients was I year (range, I-5 years). The viability and dehiscence of the two flaps and the graft survival were recorded. All patients were evaluated with objective (functional) and subjective (aesthetic) criteria. The results of the reconstruction methods were reviewed, and hand functionality was evaluated using i) the disability of the arm, shoulder, and hand (DASH) score and ii) range of motion (ROM) for the metacarpophalangeal joint (MCPJ), proximal interphalangeal joint (PIPJ), and distal interphalangeal joint (DIPJ). The DASH score comprised 30 questions, and the score ranged from 30 points, for no limitation, to 150 points, for maximum limitation. ${ }^{[8]}$ Data were transformed using the following formula: $\{[($ sum of $n$ responses $/ n)-I] \times$

Table I. Demographic properties of patients, flap size, and donor site coverage

Posterior interosseous artery flap

Number of patients

Age (years)

Sex 30.9 (SD 14.5)

Flap dimension

Donor site coverage

SD: Standard deviation.

Male/female: $6 / 5$

2249.5 (SD 628.I) $\mathrm{mm}^{2}$

Skin graft
Reverse adipofascial radial forearm flap

12

38.6 (SD 12.9)

Male/female: $9 / 3$

Primary closure 

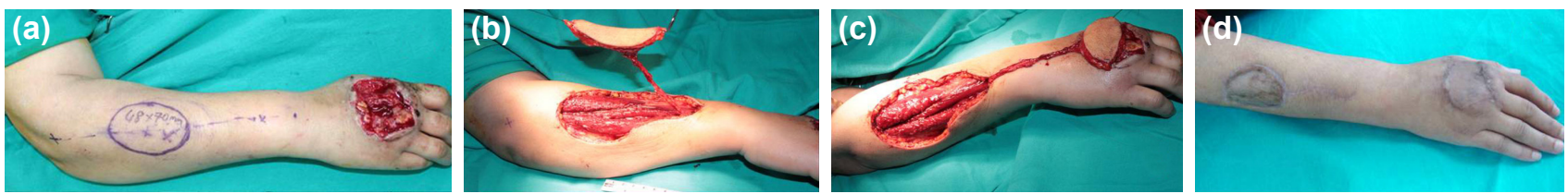

Figure 1. (a) Hand defect and flap design. (b) PIAF elevation. (c) Flap setting before subcutaneous tunneling. (d) View at 12 months postoperatively.
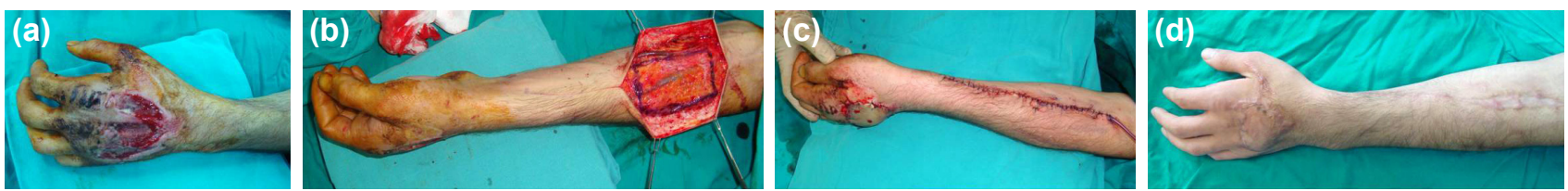

Figure 2. (a) Hand defect. (b) Adipofascial flap design. (c) Intraoperative view. (d) View at 12 months postoperatively.

25\}; this made it easy for comparison with other measures on a $0-100$ scale.

ROM for each patient was compared with the normal ROM value for MCPJ, PIPJ, and DIPJ. ${ }^{[9]}$

The outcomes were aesthetically reviewed with scar assessment measured as being excellent, good, normal, fair, and poor. This assessment was subjective.

The PIAF and RARFF flap techniques were compared in terms of operation time, length of hospital stay, and donor site problems. Donor site problems were identified as cold intolerance, numbness, and pain. These were evaluated as being either present in the patient or non-existent.

\section{Statistical Analysis}

The Mann-Whitney $U$ test and the chi-square test were used to analyze the statistical significance of the results. Continuous data were expressed as mean and standard deviation (SD).

\section{RESULTS}

Between January 2008 and December 2013, 23 patients with dorsal hand defects were treated in our clinic. The defects resulted from trauma in nine patients, infection in four, resection of tumors in six, extravasation in two, and burn in two. The hands of II patients (male/female: 6/5) were reconstructed with PIAF and the hands of 12 patients (male/female: 9/3) were reconstructed with RARFF. The mean age of the patients were 30.9 (SD, I4.5) years and 38.6 (SD, I2.9) years in the PIAF and RARFF groups, respectively. The mean sizes of the flaps were 2249.5 (SD, 628.I) $\mathrm{mm}^{2}$ and 27I3.6 $(\mathrm{SD}, 479.7) \mathrm{mm}^{2}$ in the PIAF and RARFF groups, respectively (Table I).

The RARFF donor sites were primarily closed, whereas the PIAF donor sites were covered with skin grafts. All the flaps in the RARFF group survived. In the PIAF group, two PIAF flaps underwent venous congestion, which only caused dehiscence of the sutures in one patient and partial flap necrosis in one patient. Both the partial necrosis and dehiscence healed with excision and primary suture. In the PIAF group, the donor sites covered with a graft successfully healed with no subsequent problems. The same result occurred in the RARFF donor sites that were primarily sutured. No paralysis of the posterior interosseous nerve was observed in any of the patients in the PIAF group.

There were no statistically significant differences between the PIAF and RARFF groups in terms of ROM of MCPJ, PIPJ, and DIPJ ( $p>0.05)$. The DASH scores of all the patients were similar, and no limitation in function of the upper extremity ( $p>0.05$ ) was observed (Table 2).

The patients treated with RARFF expressed their satisfaction about the operation. In the RARFF group, eight $(66.7 \%)$ of the 12 patients assessed the scar on their hand as excellent, four $(33.3 \%)$ assessed it as good, and all 12 (100\%) rated their donor site as excellent. Among the II patients treated with PIAF, seven (63.6\%) assessed the scar on their hand as excel-

Table 2. Functional results of PIAF and RARFF

\begin{tabular}{lccccc}
\hline & \multicolumn{3}{c}{ ROM (degree of angle) } & & DASH score \\
\cline { 2 - 5 } & MCPJ & PIPJ & DIPJ & 0 point & I point \\
\hline Posterior interosseous artery flap & $89.82($ SD 0.4) & 97.27 (SD 3.4) & 76.82 (SD 4.04) & $54.5 \%$ & $45.5 \%$ \\
reverse adipofascial radial forearm flap & 89.58 (SD 0.6) & 95 (SD 4.2) & 75 (SD 4.7) & $75 \%$ & $25 \%$ \\
\hline
\end{tabular}

PIAF: Posterior interosseous artery flap; RARFF: Reverse adipofascial radial forearm flap; ROM: Range of motion; DASH: Disability of the arm, shoulder and hand; MCP]: Metacarpophalangeal joint; SD: Standard deviation; PIPJ: Proximal interphalangeal joint; DIPJ: Distal interphalangeal joint. 
Table 3. Results of scar assessments of recipient and donor sites

\section{Recipient area \\ (Excellent/ good/normal/ fair/poor)}

Donor area

(Excellent/ good/normal/ fair/poor)

Fair: 8; Poor: 3

Excellent: 12
Posterior interosseous artery flap (I I patients)

reverse adipofascial radial forearm flap (12 patients)
Excellent: 7; Good: 4

Excellent: 8; Good: 4

Table 4. Comparison of operation time, length of hospital stay, venous congestion, and donor site morbidities between the two techniques

\begin{tabular}{lcccc}
\hline Reconstruction option & $\begin{array}{c}\text { Operation time } \\
(\text { minute) }\end{array}$ & $\begin{array}{c}\text { Hospitalization } \\
\text { time (day) }\end{array}$ & $\begin{array}{c}\text { Venous congestion } \\
(\mathbf{n})\end{array}$ & $\begin{array}{c}\text { Donor site morbidities (n) } \\
\text { Cold intolerance }\end{array}$ \\
\hline PIAF & I6I.8 (SD 15.3) & 5.7 (SD 0.6) & 2 & 3 \\
RARFF & II8.3 (SD 5.7) & $5.6($ SD 0.7) & 0 & 0 \\
\hline
\end{tabular}

PIAF: Posterior interosseous artery flap; RARFF: Reverse adipofascial radial forearm flap; SD: Standard deviation.

lent and four (36.4\%) assessed it as good, but eight $(72.7 \%)$ rated their donor site as fair and three $(27.3 \%)$ rated it as poor. The differences between the donor site and scar assessment for these two groups was statistically significant $(p=0.00$ I; Table 3).

The mean operation time was II8.3 (SD, 5.7) $\mathrm{min}$ in the RARFF group and 161.8 (SD, 15.3) min in the PIAF group. A statistically significant difference was found between the two groups for this variable ( $p=0.00$ I; Table 4$)$.

The mean length of hospital stay for patients treated with PIAF was 5.7 (SD, 0.6) days and that for patients treated with RARFF was 5.6 (SD, 0.7) days; there were no statistically significant differences between the groups $(p>0.05)$.

Three $(27.3 \%)$ of the I I patients who underwent PIAF identified cold intolerance as a donor site problem and nine (8I.8\%) identified numbness. None of the patients complained of pain. None of the patients in the RARFF group complained of donor site problems (Table 4).

\section{DISCUSSION}

In our study, we found that RARFF could be used for broader therapeutic indications than PIAF because there is no functional difference between the two techniques and RARFF has better aesthetic results for dorsum of hand if compared to PIAF and causes less donor site morbidity. On the other hand, PIAF may be more preferable to RARFF considering the arterial pattern. Because PIAF is a perforator flap and RARFF sacrifices the major arteries of the hand.

Hand soft tissue defects must be reconstructed with thin, pliable, hairless skin. A single-step reconstruction procedure decreases immobilization and risk of contracture. ${ }^{[10]}$ Although it is known that free flaps offer excellent reconstruction for hand defects, local flap reconstruction techniques, including PIAF and RARFF, provide simple, quick, one-step reconstruction with similar tissue. Distant flaps, including the groin and inferior hypogastric flaps, have some drawbacks, such as requiring multistage operations necessitating prolonged immobilization, which may increase morbidity and lengthen hospital stay. ${ }^{[1]}$ Liu et al. ${ }^{[2]}$ reported their experience of reconstructing hand defects with the use of reverse forearm flap that does not contain the radial or ulnar artery.

As shown in the functional outcome of this study, both PIAF and RARFF ensure that patients have the possibility of being able to use their hands in daily activities as soon as possible.

RARFF provides thin, pliable tissue and less donor site morbidity than the classic reverse radial forearm flap or PIAF. With RARFF, the skin graft is applied over the flap using only adipofascial tissue, thereby avoiding donor site morbidity. It should be noted that after radial forearm flap procedure, elevating a fascial flap will be harder for future procedures such as tenolysis or nerve reconstruction. Although RARFF has a strong blood supply, one of its major drawbacks is that a major artery is sacrificed, which compromises the viability of the hand and the radial forearm perforator flap, which preserves the radial artery. This flap doesn't need to sacrifice the radial artery and covers moderate-sized hand and wrist defects. ${ }^{[7,8]}$ RARFF gives excellent aesthetic and functional results (Tables 2, 3, and 4). As a technique, RARFF is easier to perform than PIAF. Moreover, the elevation of RARFF is faster than that of PIAF.

PIAF is a perforator flap used to cover hand defects that provides tissue quality, texture, and similar hand color. PIAF's ma- 
jor advantage is that it does not require division or sacrifice of a major artery of the hand. ${ }^{[12]}$

The technically demanding dissection time of PIAF is mentioned as a drawback, and in this study, it can be seen that the operation time was different between the two groups. Close proximity of the posterior interosseous artery to the nerve requires fastidious dissection. Injury of the posterior interosseous nerve results in motor deficits in hand function. To avoid nerve and pedicle injury, direct visualization of the posterior interosseous nerve and the pedicle is crucial. Such a demanding dissection prolongs the operation time. In our results, the operation times in the PIAF group were longer than those of the RARFF group. The difficulty in dissection and the longer operation time have been reflected in the literature and mentioned as drawbacks of the PIAF technique. ${ }^{[13]}$ RARFF provides fast and effective results for patients who are at a risk for sustained anesthesia and those for whom free flap cannot be performed.

Although the operation time for PIAF is longer than that for RARFF, the length of hospital stay did not differ between the two groups in our study.

Another drawback related to PIAF is venous congestion, which is the major cause of partial or total flap necrosis. ${ }^{[14,15]}$ In our study, we observed venous congestion due to tension exerted on the flap in two patients of the PIAF group (18.18\%) that caused suture dehiscence and partial necrosis. Incorporating a longer skin paddle over the pedicle might prevent venous congestion. Although we were able to address this problem with excision and primary saturation, there are many reports in the literature that resulted in total flap necrosis. The authors concluded that if the PIAF skin paddle extends up to the distal third of the forearm, the risk of venous congestion may decrease. In addition, compression or kinking of the vascular pedicle must be prevented. ${ }^{[14-16]}$

The eligibility of the flap depends on the results of the primary defect and donor site morbidity. In this study, no differences in the functional results were found between the PIAF and RARFF groups. The DASH scores and ROM values of both flaps were found to be similar.

Patients are mainly worried about defects related to hand reconstruction in the early postoperative period, but over time, their concern shifts to the donor site or to the aesthetic appearance of their hand. In our series, the aesthetic results for the RARFF group were better than those for the PIAF group (Table 3 ). In addition to the aesthetic results, donor site problems identified by patients in the PIAF group were worse than those identified by patients in the RARFF group (Table 4). Donor site problems, such as numbness and cold intolerance, depend on the graft application. RARFF is an improved method from the traditional reverse radial forearm flap and achieves better donor site results, both aesthetically and functionally.

The limitation of this study is that it was impossible to close all the PIA F donor defects primarily. Coban et al. ${ }^{[17]}$ showed that if donor site of posterior interosseous artery flap is closed with $\mathrm{V}$-Y advancement flaps, donor site morbidity will reduce, and this method will create a much more acceptable aesthetic scar. Further prospective studies will improve the comparison of RARFF and "adipofascial" posterior interosseous flap. Sonderegger et al. ${ }^{[18]}$ who used PIAF as adipofascial flap for radioulnar synostosis and skin was never taken with the PIAF. This retrospective study evaluated the long-term results of RARFF and PIAF using the objective and subjective criteria. This kind of studies will be guidance for surgeons to choose between the RARFF and PIAF techniques.

In conclusion, when considering the appropriate reconstruction for hand soft tissue defects, surgeons can consider RARFF as an option because it is fast and has a reliable blood supply, but it involves the sacrifice of a major blood vessel of the hand. PIAF obviates the need for the latter, but requires more time and effort for a meticulous dissection. On the other hand it has poor donor site morbidityin terms of aesthetic appearance.

\section{Conflict of interest: None declared.}

\section{REFERENCES}

1. Karamese M, Akatekin A, Abac M, Koplay TG, Tosun Z. Fingertip Reconstruction With Reverse Adipofascial Homodigital Flap. Ann Plast Surg 2015;75:158-62. [CrossRef]

2. Liu DX, Wang H, Li XD, Du SX. Three kinds of forearm flaps for hand skin defects: experience of 65 cases. Arch Orthop Trauma Surg 2011;131:675-80. [CrossRef]

3. Acharya AM, Bhat AK, Bhaskaranand $\mathrm{K}$. The reverse posterior interosseous artery flap: technical considerations in raising an easier and more reliable flap. J Hand Surg Am 2012;37:575-82. [CrossRef]

4. Kaufman MR, Jones NF. The reverse radial forearm flap for soft tissue reconstruction of the wrist and hand. Tech Hand Up Extrem Surg 2005;9:47-51. [CrossRef]

5. Keskin M, Beydes T, Tosun Z, Savaci N. Close range gun shot injuries of the hand with the "mole gun". J Trauma 2009;67:139-42. [CrossRef]

6. Appleton SE, Morris SF. Anatomy and physiology of perforator flaps of the upper limb. Hand Clin 2014;30:123-35. [CrossRef]

7. Yang D, Morris SF, Tang M, Geddes CR. Reversed forearm island flap supplied by the septocutaneous perforator of the radial artery: anatomical basis and clinical applications. Plast Reconstr Surg 2003;112:1012-6.

8. Fang QG, Shi S, Zhang X, Li ZN, Liu FY, Sun CF. Upper extremity morbidity after radial forearm flap harvest: a prospective study. J Int Med Res 2014;42:231-5. [CrossRef]

9. Bain GI, Polites N, Higgs BG, Heptinstall RJ, McGrath AM. The functional range of motion of the finger joints. J Hand Surg Eur Vol 2015;40:406-11. [CrossRef]

10. Jones NF, Jarrahy R, Kaufman MR. Pedicled and free radial forearm flaps for reconstruction of the elbow, wrist, and hand. Plast Reconstr Surg 
2008;121:887-98. [CrossRef]

11. Gong X, Lu LJ. Reconstruction of severe contracture of the first web space using the reverse posterior interosseous artery flap. J Trauma 2011;71:1745-9. [CrossRef]

12. Tan O. Reverse posterior interosseous flap in childhood: a reliable alternative for complex hand defects. Ann Plast Surg 2008;60:618-22.

13. Neuwirth M, Hubmer M, Koch $H$. The posterior interosseous artery flap: clinical results with special emphasis on donor site morbidity. J Plast Reconstr Aesthet Surg 2013;66:623-8. [CrossRef]

14. Lu LJ, Gong X, Lu XM, Wang KL. The reverse posterior interosseous flap and its composite flap: experience with 201 flaps. J Plast Reconstr Aesthet Surg 2007;60:876-82. [CrossRef]
15. Akinci M, Ay S, Kamiloglu S, Erçetin O. The reverse posterior interosseous flap: A solution for flap necrosis based on a review of 87 cases. J Plast Reconstr Aesthet Surg 2006;59:148-52. [CrossRef]

16. Angrigiani C, Grilli D, Dominikow D, Zancolli EA. Posterior interosseous reverse forearm flap: experience with 80 consecutive cases. Plast Reconstr Surg 1993;92:285-93. [CrossRef]

17. Coban YK, Gumus N, Cetinus E. Triangular design and V-Y closure of donor site of posterior interosseous artery flap. Plast Reconstr Surg 2004;114:264. [CrossRef]

18. Sonderegger J, Gidwani S, Ross M. Preventing recurrence of radioulnar synostosis with pedicled adipofascial flaps. J Hand Surg Eur Vol 2012;37:244-50. [CrossRef]

\section{ORIJIINAL ÇALIŞMA - ÖZET}

\section{Dorsal el defektlerinin yumuşak doku onarımı için posterior interosseöz arter flebi ile ters akımlı adipofasyal radyal ön kol flebinin kıyaslanması \\ Dr. Osman Akdağ, ${ }^{1}$ Dr. Gökçe Yıldıran, ${ }^{1}$ Dr. Mustafa Sütçü, ${ }^{2}$ Dr. Mehtap Karameşe ${ }^{1}$}

${ }^{1}$ Selçuk Üniversitesi Tıp Fakültesi, Plastik, Rekonstrüktif ve Estetik Cerrahi Anabilim Dalı, Konya ${ }^{2}$ Medipol Üniversitesi Tıp Fakültesi, Plastik, Rekonstrüktif ve Estetik Cerrahi Anabilim Dalı, İstanbul

AMAÇ: Bu çalışmadaki amacımız el dorsumundaki defektlerin posteriyor interosseöz arter flebi (PIA) ve ters akımlı adipofasyal radial önkol (RRÖF) ile onarım sonuçlarını kıyaslamaktır.

GEREÇ VE YÖNTEM: Geriye dönük olarak dizayn edilen bu çalışmaya 2008-20। 3 yılları arasında, PIA ile (I I hasta) ve RRÖF ile (I 2 hasta) el dorsumundaki yumuşak doku defektleri onarılan 23 hasta dahil edildi. Onarım yöntemleri fonksiyonel olarak kol, omuz ve el sorunları anketi (DASH) skoru, eklem hareket açıklı̆ı (ROM) ile; estetik olarak skarın görünümü ile değerlendirildi. Ameliyat süreleri, hastanede kalış süreleri ve donör alan problemleri kıyaslandı.

BULGULAR: Posteriyor interosseöz arter flebi ve RRÖF arasında ROM ve DASH skorları ve hastanede kalış süresi açısından istatistiksel açıdan fark saptanmadı. Ameliyat süreleri, skar değerlendirmesi ve donör alan problemleri açııından ise istatistiksel açıdan fark saptandı.

TARTIŞMA: Dorsal el defektlerinde RRÖF sonuçları PIA'dan daha iyidir, ne varki RRÖF elin ana bir arterini sakrifiye etmektedir. Anahtar sözcükler: El yumuşak doku defekti; posterior interooseöz flep; ters akımlı adipofasyal radial ön kolflebi; ters akımlı radial ön kolflebi.

Ulus Travma Acil Cerrahi Derg 20।8;24(I):43-48 doi: 10.5505/tjtes.20 I7.4II96 